Psychology. Journal of the Higher School of Economics.

2018. Vol. 15. N 2. P. 201-208. DOI: 10.17323/1813-8918-2018-2-201-208

\title{
JUDGMENTS OF LEARNING FOR WORDS IN HORIZONTAL SPACE
}

\author{
B. MARTÍN-LUENGO ${ }^{\mathrm{a}}, \mathrm{K}$. LUNA $^{\mathrm{b}}$
}

${ }^{a}$ National Research University Higher School of Economics, 20 Myasnitskaya Str., Moscore, 101000, Russian Federation

${ }^{b}$ University of Minho, Campus de Gualtar 4710-057, Braga, Portugal

\begin{abstract}
Judgments of learning are subjective estimations about the future retrieval of a recently learned piece of information. Judgments of learning might be based on valid cues, and therefore predictive of future performance or on invalid cues and not reliable. Knowing the variables that can affect judgments of learning is especially relevant in educational settings because they might influence the time spent learning new material. Embodied cognition research has shown that we have an internal numerical scale, in which lower numbers are represented on the left of a horizontal line and higher numbers on the right. Our aim was to investigate whether the spatial numerical distribution on the horizontal space is reflected on metacognitive judgements, specifically, on judgments of learning. Participants were presented with words located either on the left or on the right side of the screen. After each word and on a different screen they provided judgments of learning on a scale of 0 to 100 in deciles. After a distractor task, participants completed a recognition test. Results showed that horizontal location of the words did not affect judgments of learning nor the later recognition memory test. Our results support previous research on judgments of learning and spatial location, strengthening the conclusion that judgments of learning are a more deliberative process impervious to spatial numerical distribution.
\end{abstract}

Keywords: embodied cognition, metamemory, judgments of learning, horizontal space distribution.

\section{Introduction}

A number of studies have shown an intimate connection between magnitude and space. In Western cultures, numbers are represented in the horizontal space with small numbers on the left and large numbers on the right (Fischer \&

The article was prepared within the framework of the Basic Research Program at the National Research University Higher School of Economics (HSE) and supported within the framework of a subsidy by the Russian Academic Excellence Project "5-100". The experiment was conducted at the Psychology Research Centre (PSI/01662), University of Minho, and supported by the Portuguese Foundation for Science and Technology and the Portuguese Ministry of Science, Technology and Higher Education through national funds and co-financed by FEDER through COMPETE2020 under the PT2020 Partnership Agreement (POCI-01-0145-FEDER-007653). 
Roitmann, 2005), and in the vertical space with large numbers on the top and small numbers on the bottom (Ito \& Hatta, 2004). This intimate association is so strong that it is reflected in several effects, such as the Spatial-Numerical Association of Response Codes (SNARC; Dehaene, Bossini, \& Giraux, 1993) and the Operation Sign Spatial Association (OSSA; Pinhas, Shaki, \& Fischer, 2014). In the SNARC effect, people respond faster to numbers presented on the left when they are small $(0-4)$ than when they are large (6-9), and conversely, reaction times are faster when the numbers are large but presented on the right. In the OSSA effect, mathematical signs produce spatial biases such as that addition prime on the right and subtraction on the left (Pinhas et al., 2014). These and other similar effects suggest that this left-to-right numerical scale is innate in our representation of numbers.

Recent research has investigated whether this spatial-numerical association influences metacognitive judgments. Metacognitive judgements reflect how our cognition works. Not only are they useful, but they can be more important than the behaviour itself since they might prompt us to continue a task, finish it, or start a new one (Frith, 2012). For example, if a student thinks that she has already learnt a specific unit of study (a metacognitive estimation), she will stop reviewing the material and move on to the next unit. One of the most frequently used and extensively researched metacognitive judgments are judgments of learning (JOLs), estimations of the likelihood of subsequently recovering a recently learned piece of information (Nelson, 1990). This research focuses on the relationship between spatial location and JOL ratings.

One explanation for how metacognitive judgements are made is that we base these estimations on the use of cues that can either be valid, i.e., diagnostic of memory performance, or not (cue-utilisation approach, Koriat, 1997). If the cues on which we base our metacognitive estimations are valid, they will match later performance. For example, animate words receive higher JOLs and are remembered better than inanimate words ( $\mathrm{Li}, \mathrm{Jia}, \mathrm{Li}, \& \mathrm{Li}, 2016$ ), thus suggesting that animacy is a valid cue for JOLs. But sometimes metacognitive judgements are based on invalid or misleading cues resulting in a mismatch between the metacognitive judgements and memory. For example, words presented in large font size are rated as more memorable than words presented in small font but there is no difference in their recall (Rhodes \& Castel, 2008), showing that font size is an invalid cue for JOLs.

Recent research has studied whether spatial location is a cue for JOLs. Luna, Martín-Luengo, Shtyrov, \& Myachykov (2016) tested the effect of the vertical location of words on JOLs. There are many examples in the literature that show that positive, high, or good are located on the upper part of a vertical imaginary axis, and that in contrast negative, low, or bad are placed on the bottom (Meier \& Robinson, 2004, 2006; Meier, Hauser, Robinson, Friesen, \& Schjeldahl, 2007). For example, positive words presented on the upper part of a screen are identified faster than when placed on the lower (Meier \& Robinson, 2004). There is also a large body of metacognitive research that shows the influence of physical features on the magnitude of metacognitive judgements regardless of the actual memory performance. For example, objects are rated as more memorable when participants are 
holding a heavy clipboard rather than a light one (Alban \& Kelley, 2013). Based on these studies, Luna et al. (2016) hypothesised that words presented on the top of the screen would receive higher JOLs based on this representation of words in vertical space (up, down), and that this location would not influence memory. In two experiments controlling the location of the words and the location where the participants wrote the JOLs, Luna et al. (2016) obtained statistical evidence in support of the null hypothesis, therefore concluding that neither the location of the word on the vertical axis, nor the place of the JOL requested, affect JOLs.

The aim of the present experiment was to explore the effect of presenting words on a horizontal axis on JOLs. Specifically, we expected to find higher JOLs for words presented on the right than for the words presented on the left part of the imaginary horizontal axis, but no differences on memory performance. To test these hypotheses, participants were asked to assign JOLs to words presented on the right or left side of the screen, and then completed a recognition memory test.

\section{Method}

\section{Participants and Design}

Thirty students from the School of Psychology at the University of Minho (Portugal) completed the experiment ( 27 females and 3 males; age $\mathrm{M}=19.57$ years old, SD $=1.30$ ) in exchange for course credit. All participants spoke Portuguese as their first language. A 2 position (left, right) within-subject design was used.

\section{Materials}

Eighty-four nouns with 7 or 8 letters and linguistic frequencies between 40 and 60 per million were obtained from the Portuguese psycholinguistic database Procura-Palavras (P-PAL; Soares et al., 2014). We avoided words with emotional content (e.g., happiness) or with a spatial referent in the left-right axis (e.g., wall). We created three groups of 20,20 , and 40 words, with matched numbers of letters (all Ms between 7.45 and 7.55, all $p>.50$ ), and frequency (all Ms between 48.01 and 48.56 , all $p>.70$ ). The two groups of 20 words were used in the study phase (see below) and the group of 40 words was used in the recognition test. The last four words were used as primacy and recency buffers during the study phase.

\section{Procedure}

Participants completed the experiment individually in soundproof booths. The procedure was programmed in LiveCode (2015) and presented on a 21.5" monitor screen. Participants first read and signed a consent form and provided basic demographic information. Then the instructions mentioned that words were to appear to the left or to the right of the screen. Participants were instructed to pay attention because their memory would be tested later (i.e., intentional encoding instructions). They were also told to assign a JOL to each word. The instructions asked 
participants to "indicate on a scale from $0 \%$ to $100 \%$ your confidence that you will be able to remember the word later. If you are completely certain that you will not remember the word later, then select 0 . If you are completely sure that you will remember the word later, then select 100".

Next, 44 words were presented in a sequence that started with a fixation point ("+") in the centre of the screen for one second. Then the word was presented either to the left or the right side of the screen for three seconds. Words were assigned left or right in a fixed-random order with the only constraint that no more than two words were presented in the same position consecutively. The distance between the position of the words was approximately $37 \mathrm{~cm}$. The position was counterbalanced across participants, i.e., for half of the participants one group of words was presented to the left, and for the other half it was presented to the right. Then, on a different screen, participants gave a JOL on a scale of 0 to 100 in deciles. No labels were attached to the scale. The 11 radio buttons used to provide the JOLs were presented in the vertical centre of the screen with the $0 \%$ button to the left and the $100 \%$ button to the right. The scale was approximately $20 \mathrm{~cm}$ long. The first and last two words were included to control for primacy and recency effects and their results were not analysed.

After the 44 words, participants engaged in a filler task consisting of writing down Portuguese cities for one minute in a text box. After that, participants completed a recognition memory test that included the 40 studied words and another 40 new words in a fixed-random order, the only limitation being that no more than two words of the same category (studied left, studied right, or new) were presented consecutively. The order of studied words was different from the order used in the study phase. The participants' task was to answer yes/no to whether the word had been studied by selecting the appropriate radio button. The words appeared in the centre of the screen and participants responded at their own pace. When they finished, they were debriefed and dismissed.

\section{Results}

To test our hypotheses, we conducted pairwise Student's $t$ test between conditions and report Cohen's d unbiased $\left(d_{u m b}\right)$ as measure of effect size (Cumming, 2012). As the $t$ test only allows for rejecting the null hypothesis and does not provide evidence in its support, we also computed the Bayes Factor $(B F)$, which can provide such evidence (for an introduction to the use of the $B F$ in a study also involving judgments of learning, see Luna et al., 2016; for a more general introduction to Bayesian analysis, see Wagenmakers, Morey, \& Lee, 2016). To interpret $B F \mathrm{~s}$, we followed the standard cut-off of 0.33 and 3 as showing moderate evidence in support of the null hypothesis (i.e., no differences between conditions) and the alternative hypothesis (i.e., differences between conditions), respectively. To compute $B F$ we used the package BayesFactor (Morey \& Rouder, 2015) in R (R Core Team, 2015). The main descriptive statistics for all measures are presented in Table 1. 


\section{Judgments of Learning}

JOLs were numerically higher for words presented to the right than to the left (see Table 1). However, the difference was small and the statistical test did not allow us to reject the null hypothesis of no differences, $t(29)=0.81, p=.427, d_{u n b}=0.09$. A $B F=0.26$ provided moderate evidence in support of no differences between conditions.

\section{Memory Performance}

In a recognition test, answering that an item was presented (i.e., responding "yes") to an item actually presented is a correct response and is termed a hit in the signal-detection theory (Macmillan \& Creelman, 2005). Hits for words presented to the right or left of the screen are shown in Table 1. We also included false alarms (i.e., answering "yes" to a new item, an incorrect response) for completeness.

The results showed a minimal difference in hits between words presented to the right and to the left, and again the analyses did not allow us to reject the null hypothesis, $t(29)=1.52, p=.139, d_{u n b}=0.29$. A $B F=0.52$ showed only anecdotal evidence in support of no differences between conditions. Our results suggest that there may not be any real difference in hits between words presented to the right or to the left, but this conclusion should be taken with caution because the $B F$ did not provide strong empirical evidence in support of the null hypothesis.

\section{Discussion}

The current study aimed to test the effect of the location of words, right or left, on judgments of learning. We expected higher JOLs for words presented on the right side of the screen compared to JOLs of words on the left, and no differences in the final memory test. Results supported the null hypothesis of no influence of the location of words in the estimations of future performance and hinted that they may also not affect memory.

Part of the research on metacognition is devoted to studying how different variables can affect the subjective estimations we make about our cognitive processes. The applied importance of studies of this type relies on the use we make of metacognitive estimations. Consider a situation in which we are studying a list of vocabulary words in another language for an exam. If we wrongly believe that we

Table 1

Mean (Standard Deviation) and [95\% confidence interval] for the main measures per condition

\begin{tabular}{|l|c|c|}
\hline & Left & Right \\
\hline Judgments of Learning & $35.78(13.34)[31.01,40.56]$ & $36.98(12.02)[32.68,41.28]$ \\
\hline Hits & $.88(.11)[.84, .92]$ & $.85(.09)[.82, .89]$ \\
\hline False Alarms & \multicolumn{2}{|c|}{$.17(.10)[.13, .20]$} \\
\hline
\end{tabular}


will successfully recall this list based on the large print, we might be disappointed when we receive our test results. Some variables turn out to be valid cues and therefore predictive of performance. Other variables are not predictive of later performance but can still influence our estimations of future outcomes; that is, we believe they will affect our learning or memory even though they have no effect at all.

Our results are in line with previous research on JOLs and vertical space. Luna et al. (2016) did not find any influence on JOLs or memory for words presented either on the upper or lower part of the screen. In other words, although research in embodied cognition shows the existence of this numerical axis representation, our metamemory and our memory performance are not affected. Thus, our results are consistent with the idea that the lack of influence, either in the vertical or the horizontal axis, of numerical space location on JOLs can reflect certain automaticity of embodied processes, while metacognitive judgments can be considered more deliberative processes.

Another explanation for the lack of influence of word location and JOLs may come from the fact that for both SNARC and OSSA effects, the stimuli are numbers. For SNARC, digits are used (e.g., 1, 4) and for OSSA, numbers written in full are used (e.g., one, four). That is, the nature of our stimuli, words without any numerical referent (i.e., first-second, previous-last) might have limited the influence of the numerical space association on JOLs. Future research is necessary to further explore this and other possible explanations.

\section{References}

Alban, M. W., \& Kelley, C. M. (2013). Embodiment meets metamemory: Weight as a cue for metacognitive judgments. Joumal of Experimental Psychology: Leaming, Memory, and Cognition, $39,1628-1634$

Cumming, G. (2012). Understanding the new statistics: Effect sizes, confidence intervals, and metaanalysis. New York: Routledge.

Dehaene, S., Bossini, S., \& Giraux, P. (1993). The mental representation of parity and number magnitude. Journal of Experimental Psychology: General, 122, 371-396.

Fischer, M. H., \& Roitmann, J. (2005). Do negative numbers have a place on the mental number line? Psychology Science, 47, 22-32.

Frith, C. D. (2012). The role of metacognition in human social interactions. Philosophical Transactions of the Royal Society B, 367, 2213-2223.

Ito, Y., \& Hatta, T. (2004). Spatial structure of quantitative representation of numbers: Evidence from the SNARC effect. Memory and Cognition, 32, 662-673.

Koriat, A. (1997). Monitoring one's own knowledge during study: A cue-utilization approach to judgments of learning. Joumal of Experimental Psychology: General, 126, 349-370.

Li, P., Jia, X., Li, X., \& Li, W. (2016). The effect of animacy on metamemory. Memory and Cognition, 44, $696-705$.

LiveCode. (2015). Live Code (Version 7.1) [Computer Software]. Edinburgh, UK: LiveCode. 
Luna, K., Martín-Luengo, B., Shtyrov, Y., \& Myachykov, A. (2016). Judgments of learning for words in vertical space. Frontiers in Psychology, 7, 1894.

Macmillan, N. A., \& Creelman, C. D. (2005). Detection theory. Mahwah, NJ: Erlbaum.

Meier, B. P., \& Robinson, M. D. (2004). Why the sunny side is up: Associations between affect and vertical position. Psychological Science, 15, 243-247.

Meier, B. P., \& Robinson, M. D. (2006). Does "feeling down" mean seeing down? Depressive symptoms and vertical selective attention. Joumal of Research in Personality, 40, 451-461.

Meier, B. P., Hauser, D. J., Robinson, M. D., Friesen, C. K., \& Schjeldahl, K. (2007). What's "up" with God? Vertical space as a representation of the divine. Joumal of Personality and Social Psychology, 93, 699-710.

Morey, R. D., \& Rouder, J. N. (2015). BayesFactor: Computation of Bayes Factors for Common Designs. $R$ Package Version 0.9.12-2. Retrieved from https://CRAN.R-project.org/package=BayesFactor

Nelson, T. O. (1990). Metamemory: A theoretical framework and new findings. In Psychology of learning and motivation (Vol. 26, pp. 125-173). San Diego, CA: Academic Press.

Pinhas, M., Shaki, S., \& Fischer, M. H. (2014). Heed the signs: Operation signs have spatial associations. The Quarterly Journal of Experimental Psychology, 67, 1527-1540.

R Core Team. (2015). R: A Language and Environment for Statistical Computing. Vienna, Austria: R Foundation for Statistical Computing.

Rhodes, M. G., \& Castel, A. D. (2008). Memory predictions are influenced by perceptual information: evidence for metacognitive illusions. Journal of Experimental Psychology: General, 137, 615-625.

Soares, A. P., Iriarte, A., Almeida, J. J., Simões, A., Costa, A., França, P., ... Comesaña, M. (2014). Procura-PALavras (P-PAL): Uma nova medida de frequencia lexical do Portuguęs Europeu contemporâneo [Procura-PALavras (P-PAL): A new measure of word frequency for contemporary European Portuguese]. Psicologia: Reflexăo e Crítica, 27, 1-14. Retrieved from http://ppal.di.uminho.pt (in Portugal)

Wagenmakers, E. J., Morey, R. D., \& Lee, M. D. (2016). Bayesian benefits for the pragmatic researcher. Current Direction in Psychological Science, 25, 169-176.

Beatriz Martín-Luengo - postdoc fellow, Institute for Cognitive Neuroscience, Center for Cognition and Decision Making, National Research University Higher School of Economics, Ph.D.

Research area: metamemory, memory, conversational pragmatics, experimental psychology, cognitive psychology, cognitive neuroscience.

E-mail: bmartinluengo@hse.ru

Karlos Luna - postdoc fellow, the Psychology Research Centre, School of Psychology, University of Minho (Portugal), Ph.D.

Research area: human memory, metamemory, eyewitness memory, experimental psychology, cognitive psychology.

E-mail: karlos.luna@psi.uminho.pt 


\title{
Суждения о запоминании слов в горизонтальном пространстве
}

\author{
Б. Мартин-Луенго ${ }^{\mathrm{a}}$, К. Луна \\ ${ }^{\alpha}$ Национальный исследовательский университет «Высиая икола экономики», 101000, Россия, \\ Москва, ул. Мясниикая, д. 20 \\ ${ }^{\text {` }}$ ниверситет Минъю, 4704-553, Португалия, Брага, Largo do Paço
}

\begin{abstract}
Резюме
Суждения о запоминании являются субъективными предположениями о возможности вспомнить только что выученную информацию. Суждения могут основываться на валидных маркерах и тем самым предугадывать дальнейшую эффективность или, в случае с невалидными маркерами, иметь обратный эффект. Изучение переменных, влияющих на суждения о запоминании, особенно важно в образовании, так как они могут существенно ускорить процесс усвоения нового материала. Исследования воплощенного сознания показывают, что мы имеем внутреннюю ментальную цифровую шкалу, в которой малье числа находятся слева по горизонтальной шкале, а большие числа - справа. Целью нашего исследования стала попытка понять, влияет ли пространственное цифровое распределение по горизонтальной линии на метакогнитивные суждения, конкретнее - на суждения о запоминании. Участники запоминали слова, появляющиеся либо слева, либо справа на экране. После каждого слова участники выдавали свои суждения о запоминании на шкале от 0 до 100 на другом мониторе. После отвлекающей задачи участники выполняли тест на узнавание слов. Результаты показали, что горизонтальное положение слов при запоминании не влияло ни на суждения, ни на показатели в тесте. Результаты нашей работы поддерживают предыдущие исследования, заключая, что пространственная цифровая дистрибуция не влияет на суждения о запоминании.
\end{abstract}

Ключевые слова: воплощенное сознание, метапамять, суждения о запоминании, горизонтальная числовая дистрибуция.

Беатриз Мартин-Луенго - постдок, Центр нейроэкономики и когнитивных исследований, Национальный исследовательский университет «Высшая школа экономики», Ph.D.

Сфера научных интересов: метапамять, память, прагматика речи, экспериментальная психология, когнитивная психология, когнитивная нейронаука.

Контакты: bmartinluengo@hse.ru

Карлос Луна - постдок, Научно-исследовательский центр психологии, Школа психологии, Университет Минью (Португалия), Ph.D.

Сфера научных интересов: человеческая память, метапамять, память свидетелей, экспериментальная психология, когнитивная психология.

Контакты: karlos.luna@psi.uminho.pt 